\title{
Correlation between Allergic Rhinitis and Rhinosinusitis in ENT Outpatient Clinic Patients
}

\author{
Felicia Alvita Tjahjono $^{1}$, Irwan Kristyono ${ }^{2 *}$, Ari Baskoro ${ }^{3}$ \\ ${ }^{1}$ Faculty of Medicine Universitas Airlangga, Surabaya, Indonesia \\ ${ }^{2}$ Department of Otorhinolaryngology-Head and Neck Surgery, Faculty of Medicine - Dr. Soetomo General Hospital, Surabaya, \\ Indonesia \\ ${ }^{3}$ Department of Internal Medicine, Faculty of Medicine, Universitas Airlangga - Dr. Soetomo General Hospital, Surabaya, \\ Indonesia
}

\section{A R T I C L E I N F O}

\section{Article history:}

Received 13 May 2020

Received in revised form 27 May 2020

Accepted 01 June 2020

Available online 30 June 2020

\section{Keywords:}

Rhinosinusitis,

Allergic rhinitis,

Atopy,

Skin prick test.

*) Corresponding author: irwank63@gmail.com

\begin{abstract}
A B S T R A C T
Introduction: Rhinosinusitis and allergic rhinitis are common health problems. Allergic rhinitis patients tend to have edema on their nasal mucosa, disrupted cilia, and excessive secrete production that clogged paranasal sinuses' ostiums and lead to inflammation and infection of the paranasal sinuses. There is still a contradiction of allergic rhinitis as predisposing factor of rhinosinusitis. Those correlation is not yet clear, thus we aim to analyze the correlation between allergic rhinitis and rhinosinusitis.

Methods: This study was a cross-sectional design. The samples were obtained by consecutive sampling. Adult patients above 19 years old with nasal discharge were examined by the doctors on duty and interviewed. Medical data obtained was recorded and analyzed using chi square test.

Results: From 98 patients, 17 patients $(17.35 \%)$ had both rhinosinusitis and allergic rhinitis, 48 patients (48.98\%) only had rhinosinusitis, and 13 patients $(13.26 \%)$ only had allergic rhinitis. Patients who had neither rhinosinusitis nor allergic rhinitis reported to be 20 patients $(20.41 \%)$. Chi square test showed that allergic rhinitis had no significant correlation with rhinosinusitis $(p=0.266)$. Conclusion: There is no significant correlation between allergic rhinitis and rhinosinusitis. Rhinosinusitis is a multifactorial disease.
\end{abstract}

\section{Introduction}

Rhinosinusitis is described as an inflammation of the nasal and paranasal sinuses mucosa. Signs and symptoms are nasal congestion or blockage, nasal discharge or postnasal drip, facial pain, and reduction or loss of smell. One of many factors predisposing rhinosinusitis is allergic rhinitis. ${ }^{1}$ Relation between allergic rhinitis and rhinosinusitis might be multifactorial. Anatomically, allergic rhinitis patients tend to have nasal mucosal edema, disrupted cilia, and excessive secrete production. Those lead to blockage of the paranasal sinuses' ostiums and infection. ${ }^{2}$

Rhinosinusitis is a common health problem. There are two types of rhinosinusitis, acute and chronic. Acute rhinosinusitis resolves in 12 weeks while chronic rhinosinusitis does not resolve and continues for more than 12 weeks. Prevalence of acute and chronic rhinosinusitis in Europe are around $6-15 \%$ and 5-15\%. Adults could get acute rhinosinusitis 2-5 times in a year while children 7-10 times in a year. Predisposing factors are air pollution, high air humidity, allergy, tobacco smoking, nasal anatomic abnormalities such as septum deviation and polyps, gastro esophageal reflux disease, depression, antibiotic resistance, and abnormality of the cilia. ${ }^{1}$

Allergic rhinitis is a non-infectious rhinitis. Signs and symptoms are sneezing, itchy nose, non-purulent and bilateral nasal discharge, nasal blockage, red, itchy, and watery eyes, and edema of the conjunctiva. ${ }^{1,3}$ Prevalence of allergic rhinitis in the USA is $10-30 \%$ in adults and $40 \%$ in children. ${ }^{4}$ Common causes are allergens such as pollen, fungi, house dust mite, animals fur, rodent, and cockroach. ${ }^{5}$ Comorbidities could be conjunctivitis, chronic otitis media, Eustachian tube dysfunction, obstructive sleep apnea, rhinosinusitis, loss of smell, skin rash, headache, gastro esophageal reflux disease, and asthma. ${ }^{3,4}$

There are differences in studies' results about allergic rhinitis as a predisposing factor of rhinosinusitis. A European position paper on rhinosinusitis and nasal 
polyps consists of review of many papers mentioned that there was significant correlation between allergic rhinitis and rhinosinusitis. Allergic rhinitis patients had a risk of rhinosinusitis 4.4 times greater than healthy people. However one paper stated that the different prevalence of rhinosinusitis in allergic rhinitis patients and healthy people aware not significant. On the other hand, another paper also could not find enough evidence of allergic rhinitis role in acute rhinosinusitis. ${ }^{1}$

Those different opinion shows that correlation between allergic rhinitis and rhinosinusitis is not clearly understood. This study aims to analyze the correlation between allergic rhinitis and rhinosinusitis.

\section{Methods}

Data were obtained from Dr. Soetomo General Hospital Ear, Neck and Throat (ENT) outpatient clinic during January-February 2017. All patients with symptom of nasal discharge above 19 years old were interviewed and examined by the doctor in charge. Patients with suspicion of allergic rhinitis underwent skin prick test.

Rhinosinusitis was diagnosed by interview and physical examination using anterior rhinoscopy. Rhinosinusitis could be diagnosed if there were at least two symptoms, one of which should be nasal blockage/congestion or nasal discharge/postnasal drip. Other symptoms could be facial pain or reduction/loss of smell. ${ }^{1,6}$ Examination with anterior rhinoscopy could show inflammation or edema of the mucosa, purulent nasal discharge, polyps, or septum deviation. ${ }^{1}$

Allergic rhinitis was diagnosed by skin prick test. Allergens were dropped on the volar side of the forearm then pricked with a lancet. Positive reaction showed wheal more than $3 \mathrm{~mm}$ diameter after 15-20 minutes. ${ }^{7}$ Symptoms present were nasal blockage, itchy nose, sneezing, nasal discharge, postnasal drip, itchy soft palate, itchy throat, lethargic, morning or afternoon sleepiness, dry mouth, itchy eyes, habit of rubbing the nose called allergic salute, breathing through the mouth. ${ }^{3,8,9}$ Examination with anterior rhinoscopy could show inflammation or boggy mucosa and excessive production of non-purulent nasal discharge. ${ }^{10}$

Patients were given information to consent, some of them who agreed to join this study as subjects signed informed consent letter. Data from interview and physical examination was recorded. All data analyses were performed using IBM SPSS 23.0 (New York, USA). The data was analyzed using chi square test with a significant value of $\mathrm{p}<0.05$.

\section{Results}

Data was obtained from 98 patients. There were 65 patients $(66.33 \%)$ with rhinosinusitis and 17 of those patients $(17.35 \%)$ with allergic rhinitis. The other 33 patients $(33.67 \%)$ did not have rhinosinusitis and 13 of those patients (13.27\%) had allergic rhinitis. Women were found to be more predominant in both rhinosinusitis and allergic rhinitis with proportions of $58.46 \%$ and $63.33 \%$ consecutively. Youngest patient of both rhinosinusitis and allergic rhinitis was 20 years old. Oldest patient of rhinosinusitis and allergic rhinitis were 74 years old and 73 years old consecutively. Mean age of rhinosinusitis and allergic rhinitis patients were 42.66 years old and 40.1 years old consecutively. Range of age with the most and the least of rhinosinusitis patients were 50-59 years old with proportion of $27.69 \%$ and $60-69$ years old with proportion of $4.62 \%$ consecutively. Range of age with the most and the least of allergic rhinitis patients were $20-29$ years old with proportion of $33.33 \%$ and more than 69 years old with proportion of $3.33 \%$ consecutively. Housewives were found to be the most predominant in both rhinosinusitis with proportion of $24.62 \%$ and allergic rhinitis with proportion of $23.33 \%$.

Table 2.Clinical characteristics of rhinosinusitis. $(n=65)$

\begin{tabular}{lc}
\hline \multicolumn{1}{c}{ Clinical characteristics } & $\mathbf{n ~ ( \% )}$ \\
\hline Main symptoms & $65(100.00)$ \\
\hline Nasal discharge/postnasal drip & $58(89.23)$ \\
\hline Nasal blockage/congestion & $40(61.54)$ \\
\hline Facial pain & $24(36.92)$ \\
\hline Reduction/loss of smell & \\
\hline Accompanying symptoms & $45(69.23)$ \\
\hline Headache & $34(52.31)$ \\
\hline Sleep disturbance & $28(43.08)$ \\
\hline Malaise & $26(40.00)$ \\
\hline Cough & $22(33.85)$ \\
\hline Fever & $20(30.77)$ \\
\hline Dysphonia & $20(30.77)$ \\
\hline Sore throat & $15(23.08)$ \\
\hline Toothache & $11(16.92)$ \\
\hline Ear pain & $2(3.08)$ \\
\hline Drowsiness
\end{tabular}

Table 3. Clinical characteristics of allergic rhinitis. $(n=30)$

\begin{tabular}{|c|c|}
\hline Clinical characteristics & n (\%) \\
\hline \multicolumn{2}{|c|}{$\begin{array}{l}\text { Positive reactions in skin prick test done at } \\
\text { Dr. Soetomo General Hospital ENT outpa- } \\
\text { tient clinic }(\mathrm{n}=17)\end{array}$} \\
\hline House dust mite & $15(88.24)$ \\
\hline Dog fur & $11(64.71)$ \\
\hline Cat fur & $11(64.71)$ \\
\hline Kapok & $11(64.71)$ \\
\hline \multicolumn{2}{|l|}{ History of atopy in family $(n=30)$} \\
\hline Yes & $11(36.67)$ \\
\hline No & $19(63.33)$ \\
\hline
\end{tabular}

Table 4. Correlation between allergic rhinitis and rhinosinusitis

\begin{tabular}{lccc}
\hline & $\begin{array}{c}\text { Diagnosed } \\
\text { with rhinosi- } \\
\text { nusitis }\end{array}$ & $\begin{array}{c}\text { Not diagnosed } \\
\text { with rhinosinusitis }\end{array}$ & ps \\
\hline $\begin{array}{l}\text { Allergic } \\
\text { rhinitis }\end{array}$ & $17 / 65$ & $13 / 33$ & 0.266 \\
\hline
\end{tabular}


Table 1. Subjects characeristics. $(\mathrm{n}=98)$

\begin{tabular}{|c|c|c|c|c|}
\hline Characteristics & $\begin{array}{c}\text { Rhinosinusitis } \\
\text { with allergic rhi- } \\
\text { nitis }(\mathrm{n}=17)\end{array}$ & $\begin{array}{l}\text { Rhinosinusitis with- } \\
\text { out allergic rhinitis } \\
(\mathrm{n}=48)\end{array}$ & $\begin{array}{l}\text { Without rhinosi- } \\
\text { nusitis with allergic } \\
\text { rhinitis }(n=13)\end{array}$ & $\begin{array}{l}\text { Without rhinosinus- } \\
\text { itis without allergic } \\
\text { rhinitis }(n=20)\end{array}$ \\
\hline & $\mathrm{n}(\%)$ & $\mathrm{n}(\%)$ & $\mathrm{n}(\%)$ & $\mathrm{n}(\%)$ \\
\hline \multicolumn{5}{|l|}{ Gender } \\
\hline Men & $6(6.12)$ & $21(21.43)$ & $5(5.10)$ & $10(10.20)$ \\
\hline Women & $11(11.22)$ & $27(27.55)$ & $8(8.16)$ & $10(10.20)$ \\
\hline \multicolumn{5}{|l|}{ Age } \\
\hline $20-29$ years old & $4(4.08)$ & $13(13.26)$ & $6(6.12)$ & $5(5.10)$ \\
\hline $30-39$ years old & $4(4.08)$ & $7(7.14)$ & $1(1.02)$ & $2(2.04)$ \\
\hline $40-49$ years old & $2(2.04)$ & $10(10.20)$ & $5(5.10)$ & $2(2.04)$ \\
\hline $50-59$ years old & $5(5.10)$ & $13(13.26)$ & $0(0.00)$ & $7(7.14)$ \\
\hline $60-69$ years old & $1(1.02)$ & $2(2.04)$ & $1(1.02)$ & $4(4.08)$ \\
\hline$>69$ years old & $1(1.02)$ & $3(3.06)$ & $0(0.00)$ & $0(0.00)$ \\
\hline \multicolumn{5}{|l|}{ Occupation } \\
\hline Housewife & $4(4.08)$ & $12(12.24)$ & $3(3.06)$ & $3(3.06)$ \\
\hline Entrepreneur & $4(4.08)$ & $11(11.22)$ & $2(2.04)$ & $6(6.12)$ \\
\hline Student & $2(2.04)$ & $6(6.12)$ & $3(3.06)$ & $1(1.02)$ \\
\hline Not working & $2(2.04)$ & $5(5.10)$ & $1(1.02)$ & $2(2.04)$ \\
\hline Private employees & $2(2.04)$ & $4(4.08)$ & $1(1.02)$ & $4(4.08)$ \\
\hline Civil worker/Soldier & $2(2.04)$ & $3(3.06)$ & $2(2.04)$ & $2(2.04)$ \\
\hline Paramedic & $1(1.02)$ & $2(2.04)$ & $0(0.00)$ & $2(2.04)$ \\
\hline Other & $0(0.00)$ & $5(5.10)$ & $1(1.02)$ & 0 \\
\hline
\end{tabular}

\section{Discussion}

Correlation between allergic rhinitis and rhinosinusitis was not significant. Study conducted in Europe showed similar result. ${ }^{11}$ However study in America showed there was significant correlation between allergic rhinitis and chronic rhinosinusitis. ${ }^{12}$ This difference might be a result of difference in research design, inclusion criteria, and characteristics of the population. ${ }^{13}$

Nasal mucosal edema in allergic rhinitis patients obstructs the paranasal sinuses' ostiums and leads to mucus retention. Furthermore, there are excessive production of secrete and disruption of the cilia. Mucus retention and disruption of the cilia can interfere with mucociliary clearance..$^{1,2}$

Mucociliary clearance is a mechanism to get rid pathogens and foreign objects out of the body. Respiratory tract has 2 layers of airway surface liquid. The upper layer is a layer of thick mucus consists of mucin secreted by the goblet cell and sub mucosal glands. Pathogens, foreign objects, and debris are trapped in this layer. The lower layer is a periciliary layer consists of thin liquid that surrounds the cilia. This liquid helps the cilia moves faster and coordinately to get the mucus into the oropharynx to either be coughed out or swallowed in. ${ }^{14}$ Disruption of this mechanism leads to the inability of clearing out any pathogens, foreign bodies, or debris that trapped in the mucus. This condition facilitates secondary bacterial infection. Moreover, change of normal flora in the paranasal sinuses is found in allergic rhinitis patients. ${ }^{1,2,15}$

On the other hand, Desrosiers et al. (2012) stated that the role of nasal mucosal edema, obstruction of paranasal sinuses ostiums, mucus retention, and infection in rhinosinusitis were not clear. High eosinophil infiltration was found in both atopic patients and non-atopic patients. Immunoglobulin $\mathrm{E}$ production was found in chronic rhinosinusitis patients with or without history of allergy along with negative reactions to allergens in skin prick test.6 Baroody et al in Feng et al. (2012) claimed that nasal allergen challenge in allergic rhinitis patients induced eosinophilic inflammation of the paranasal sinuses. $^{2}$

Data from a study conducted in the USA showed that prevalence of allergic rhinitis was $20 \%$ whereas $50 \%$ of the USA population had immunoglobulin E sensitization. This showed that a positive reaction to allergen in skin prick test meant sensitization and could not prove the correlation between allergic rhinitis and rhinosinusitis. ${ }^{13}$

Correlation between allergic rhinitis and rhinosinusitis may be multifactorial. There are many predisposing factors other than allergic rhinitis such as air pollution, anatomic abnormality, genetic, tobacco smoking, viral or bacterial infection, immunodeficiency, biofilm, and gastro esophageal reflux disease. ${ }^{2}$ Air pollution, primary ciliary dyskinesia, tobacco smoking, and viral or bacterial infection disrupt the mucociliary clearance. Immunodeficiency and biofilms in polyps facilitate bacterial colonization and infection. ${ }^{1,16}$

Occupation with the biggest proportion in rhinosinusitis was housewives. Exposures to dust was risk factor for chronic rhinosinusitis therefore housework which requires cleaning up dust had relation with rhinosinusitis. ${ }^{17}$

The number of subjects in this study was relatively small 
due to limitation of time of data collection. Future study can be improved by distinguishing acute rhinosinusitis from chronic rhinosinusitis, distinguishing intermittent allergic rhinitis from persistent allergic rhinitis, and using sample size calculation.

\section{Conclusion}

There was no significant correlation between allergic rhinitis and rhinosinusitis. Rhinosinusitis is a multifactorial disease.

\section{Conflict of Interest}

The author stated there is no conflict of interest.

\section{References}

1. Fokkens WJ, Lund VJ, Mullol J, Bachert C, Alobid I, Baroody F et al. European position paper on rhinosinusitis and nasal polyps 2012 . Rhinology supplement 2012; 23:1-298.

2. Feng $\mathrm{CH}$, Miller MD, Simon RA. The united allergic airway: Connections between allergic rhinitis, asthma, and chronic sinusitis. American Journal of Rhinology and Allergy 2012; 26:18-190.

3. Scadding GK, Scadding, GW. Diagnosing allergic rhinitis. Immunology and Allergy Clinics of North America 2016; 36:249260 .

4. Meltzer, EO. Allergic rhinitis. Burden of illness, quality of life, comorbidities, and control. Immunology and Allergy Clinics of North America 2016; 36:235-248.

5. Papadopoulos NG, Guibas GV. Rhinitis subtypes, endotypes, and definitions. Immunology and Allergy Clinics of North America 2016; 36:215-233.

6. Desrosiers M, Evans GA, Keith PK, Wright ED, Kaplan A, Bouchard $\mathrm{J}$ et al. Canadian clinical practice guidelines for acute and chronic rhinosinusitis. Allergy, Asthma \& Clinical Immunology 2012; 7:2.
7. Heinzerling L, Mari A, Bergmann K, Bresciani M, Burbach G, Darsow U et al. The skin prick test - European standards. Clinical and Translational Allergy 2013; 3:3.

8. Jaruvongvanich V, Mongkolpathumrat $\mathrm{P}$, Chantaphakul $\mathrm{H}$, Klaewsongkram J. Extranasal symptoms of allergic rhinitis are difficult to treat and affect quality of life. Allergology International 2016; 65:199-203.

9. Rotiroti G, Scadding GK. Allergic rhinitis-an overview of a common disease. Paediatrics and Child Health 2016.

10. Chaaban M, Corey JP. Pharmacotherapy of rhinitis and rhinosinusitis. Facial Plastic Surgery Clinics of North America 2012; 20:61-71.

11. Min JY, Tan BK. Risk factors for chronic rhinosinusitis. Current Opinion in Allergy and Clinical Immunology 2015; 15(1):1-13.

12. Tan BK, Chandra RK, Pollak J, Kato A, Conley DB, Peters AJ et al. Incidence and associated premorbid diagnoses of patients with chronic rhinosinusitis. Journal of Allergy and Clinical Immunology 2013; 131:1350-1360

13. Orlandi RR, Kingdom TT, Hwang PH, Smith TL, Alt JA, Baroody $\mathrm{FM}$ et al. International consensus statement on allergy and rhinology: Rhinosinusitis. Interational Forum of Allergy and Rhinology 2016; 6:S22-S209.

14. Stevens WW, Lee RJ, Schleimer RP, Cohen NA. Chronic rhinosinusitis pathogenesis. Journal of Allergy and Clinical Immunology 2015; 136:1442-1453.

15. Choi CH, Poroyko V, Watanabe S, Jiang D, Lane J, deTineo M et al. Seasonal allergic rhinitis affects sinonasal microbiota. American Journal of Rhinology and Allergy 2014; 28:281-286.

16. Hamilos DL. Chronic rhinosinusitis: Epidemiology and medical management. Journal of Allergy and Clinical Immunology 2011; 128:693-707.

17. Gao WX, Ou CQ, Fang SB, Sun YQ, Zhang H, Cheng L et al. Occupational and environmental risk factors for chronic rhinosinusitis in China: a multicenter cross-sectional study. Respiratory Research $2016 ; 17: 54$ 